Volume 4 • Nomor $1 \cdot$ Oktober 2020

Pege (Hal.) : $33-51$

(C) Universitas Pamulang

JL.Surya Kencana No.1 Pamulang, Tangerang Selatan - Banten

Telp. (021) 7412566, Fax (021) 7412491

website. :

Email : jurnalmarketing.unpam@gmail.com

\title{
Factors Influencing Consumer's Intention to Buy Furniture Online in Greater Jakarta, Indonesia
}

\author{
Vania Valencia ${ }^{1}$; Santoso ${ }^{2}$; Pradita Eka Pebrianti ${ }^{3}$; Muhammad Aries Satria Raharjo ${ }^{4}$ \\ ${ }^{1-4)}$ Universitas Prasetiya Mulya, Jakarta, email : vaniavlncia@gmail.com
}

\begin{abstract}
The purpose of this research was to examine the factors that affect the consumer's intention to purchase furniture via online store in Greater Jakarta. Some of the factors that considered by this research as a baseline on this journal were the consumer perceptions, perceived risk and perceived benefits. In addition, this research adding another relationship between consumer's attitude and intention to make a purchase online. An Internet-administered survey method use to Greater Jakarta citizen. Results of this research have shown that online shopping is begin to be considered successfully provide a substantial benefit to the consumer, even though the risk factor proportion still exist. The findings also show that the increased attitudes of Greater Jakarta consumers towards online furniture shopping have been significantly affected by consumer perception and benefit.
\end{abstract}

Keywords: furniture; consumer's attitude; consumer's intention to buy; consumer's perception; online shopping; perceived benefit; perceived risk.

Abstrak. Tujuan dari penelitian ini adalah untuk menguji faktor-faktor yang mempengaruhi intensi konsumen untuk membeli mebel melalui toko online di Jabodetabek. Beberapa faktor yang dipertimbangkan dalam penelitian sebagai dasar jurnal ini adalah persepsi konsumen, persepsi risiko dan persepsi manfaat. Sebagai tambahan, penelitian ini menambahkan hubungan antara sikap dan intensi konsumen untuk melakukan pembelian online. Metode survei melalui internet digunakan pada penduduk di Jabodetabek. Hasil penelitian menunjukan bahwa belanja online mulai dinilai berhasil memberikan manfaat yang cukup besar kepada konsumen, meskipun proporsi faktor resiko masih tetap ada. Temuan juga menunjukkan bahwa peningkatan sikap konsumen atas pembelian online mebel secara signifikan dipengaruhi oleh persepsi dan manfaat yang diterima konsumen.

Keywords: mebel; perilaku konsumen; intensi pembelian konsumen; persepsi konsumen; belanja online; persepsi manfaat; persepsi risiko.

\section{A. INTRODUCTION}

The internet can be considered as one of the most successful innovations in information technology sector. A lot of people around the world are using the internet. It can be seen through the high number of global internet population which has reached, 7.676 billion or $56 \%$ of world's total population (We are Social, 2019). However, in some countries, particularly the developing ones, the acceptance rate of internet is lower compared to the developed countries (IAMAI, 2013).

The internet gained its popularity because of the characteristics such as flexible, interactive, and allows personalization, which increased convenience for the users. 
Moreover, the internet also can be used for personal, professional, or even business purposes. Hence, there are lot of users begin to include the use of internet for the innovative business strategy. It has led to unique and revolutionary transformations for trade activity. Nowadays, individuals, groups, and organizations can perform trade without having face to face interaction through "online shopping".

Unfortunately, although online shopping increased convenience for the seller and buyer, it contributes to the increasing competition for traditional shopping channels. In the article, Malls Going to Walls (2010), it stated that online shopping can cannibalize the brick-andmortar store as the consumers getting more familiar with it.

Compared to the brick-and-mortar store, online shopping allows the consumers to be more efficient in time and energy spending to obtain product which they need. Because, the internet has reduced the time and space limit which presence in brick-and-mortar store. Other benefits of online shopping are saving more cost (Reibstein, 2002) and wide range variety of products (Keeney, 1999). Despite various functional advantages, online shopping has some clear disadvantages that consumers can not feel or touch the product or delay delivery and possession of the product.

According to the model proposed by Bhatnagar and Ghosh (2004), the perception of risks and benefits is one of the main antecedents of purchase action. Due to, it has been the nature of humans to seek for advantage. Consumers will make a purchase action if they perceived that the advantage will be greater than the risk.

Because of that Forrester (in Gracia, 2018) believed that the acceptance rate of online shopping is not equal across industry. In the furniture industry, the acceptance rate might be lower. It is because, the price of furniture is high and consumer sees it as a major investment to be used for years to come. Therefore, they have desire to see the product physically before making a purchase. Another reason of low acceptance rate is shipping fee for furniture is not cheap. Despite of that, several players in furniture industry decided to set up an e-commerce to support online shopping. IKEA is one of them as they have invented the flat-packaging method, which can cut shipping fee for consumer. However, it begs a question, is it enough to make the consumer shift to online shopping for furniture?

To find out, a comprehensive research on consumer purchase intention to shop furniture online should be conducted. As the result can help business managers to develop appropriate marketing strategies for online furniture shopping and provide reference for the transformation of business mode of furniture manufacturing enterprises.

The research should be conducted in Indonesia as it has obtained the title as one of the largest markets for online shopping in the world with total internet users 143.26 million. Moreover, in 2019, it also has high internet penetration rate which slightly above $50 \%$. It indicated that the market for online shopping is significantly grown from year to year in Indonesia.

Indonesia has long been known as one of the leading furniture manufacturers in the world. Its teak and rattan products are sought after both on the local and international markets. Nevertheless, given its inherent competitive advantages in terms of raw materials, numerous bureaucratic hurdles have hampered the development of the furniture industry. Indonesia is currently the fourth largest exporter in ASEAN despite its extensive timber resources. Despite a setback in 2016, in 2017, the furniture industry in Indonesia managed to acquire the positive growth. With the $1 \%$ increase compared to last year, the value of Indonesian furniture exports in 2017 reached USD \$1,627 billion (HIMKI, 2018). There are a lot of business units engage in furniture industry. Data from Ministry of Industry (2015) revealed that there are 139,544 business units involved and employed almost five thousand workers. Also, the investment value has reached 5.8 trillion IDR. The industry has been included by the government as a priority as it is labor intensive and has a healthy grown from year to year (Indonesia Global Business, 2018). 
In consequences of the furniture growth and the possibility of sustainability on this furniture industry, the internet might be considered has provided a significant support increasing the growth of the furniture industry. This statement was supported by data as shown in Figure 1. where the data indicates the growth of the number of internet users in Indonesia from 2017 - 2023.

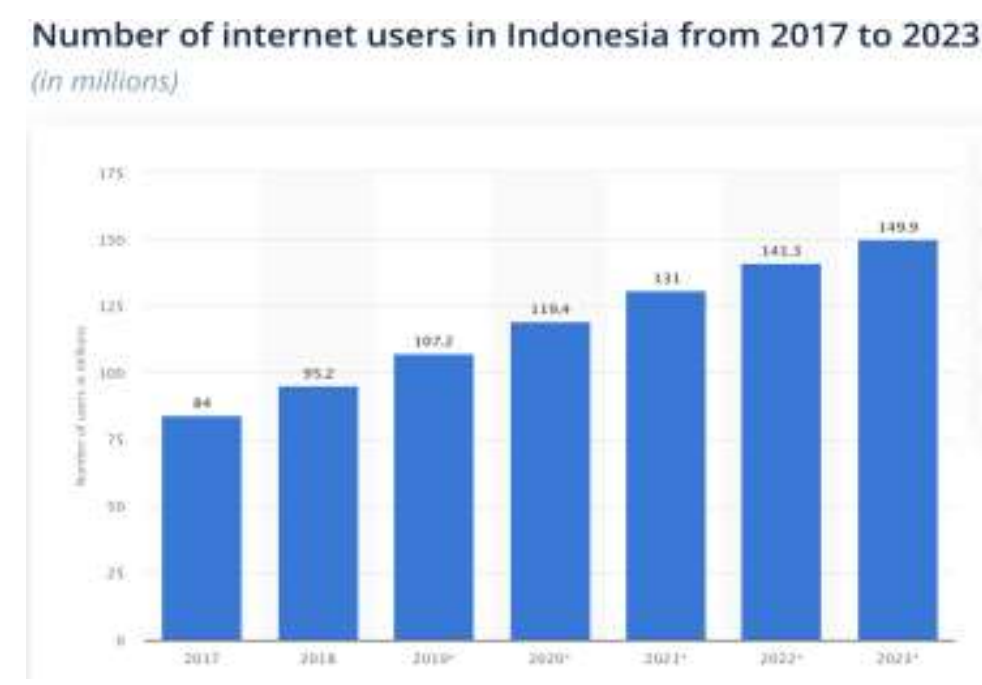

Source: Statista, 2019

Figure 1. Indonesia: Number of internet users 2017-2023

In addition to that, in the last few years, the furniture industry in Indonesia is growing rapidly; the market is expanding because of the contribution of online sales. It is predicted that the online sales will continue to grow and contribute $21 \%$ of total market value by 2023 as shown in Figure 2 below.

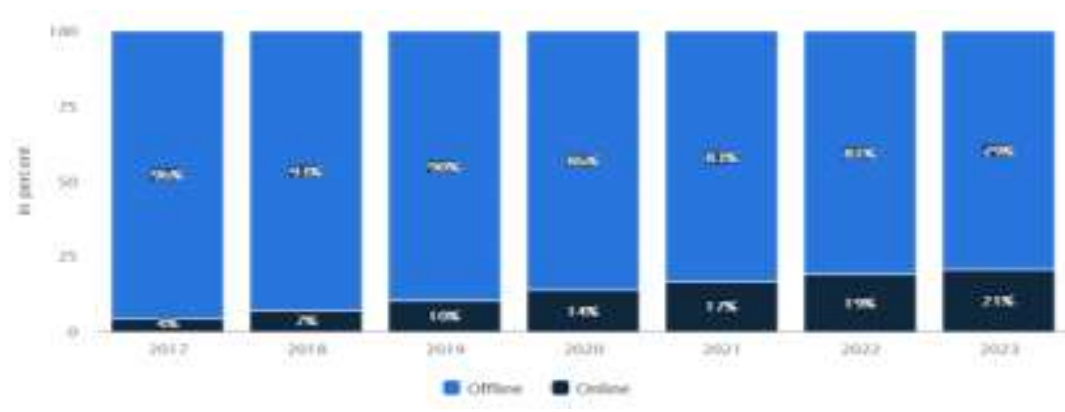

Source: Statista, September 2019

Figure 2. Total Market Furniture Indonesia through online sales

According to the analysis from Mordor Intelligent, the CAGR of furniture industry in Indonesia is expected to reach $3.5 \%$ during the forecast period. The country has been recognised as one of the leading furniture manufacturers in the world. Most produced furniture products are made from teak and rattan, which marketed both locally and internationally.

Greater Jakarta is deemed as the most populous in Indonesia, where aside than most of the internet user were located in Greater Jakarta, it is acceptable to deemed that the prospected furniture buyer were also located in Greater Jakarta. Therefore, this research will specifically conducted to examine factors-factors that affected consumer attitude in 
Greater Jakarta towards the activity of purchasing furniture by way of online store to support the sustainability and growth of furniture industry which has been engaged on the internet industry.

There are several factors that considered will affect consumer attitude and consumer intention before decide to make a purchase. Mostly, the consumer will compare between the risk and benefit they received when make a purchase either by online or offline store. Therefore, the purpose of this research was to identify the relationship between the risk and benefit factor, to analyze the consumer perception and how it might influent the consumer attitude and intention towards buying furniture online.

\section{B. LITERATURE REVIEW}

\section{Consumer Perceptions-Tendency Of Trust}

The tendency of trust is the general tendency or degree that an individual is willing to trust others in interpersonal communication (Rotter 1971). It is a concept of psychology, influenced by factors such as personality, experience, and social background, and varies from person to person (Xu 2016). Everyone has different personality characteristics, life experiences, social experiences, and cultural backgrounds, and these backgrounds synthetically create the consumer's personal trust tendencies (Li 2007).

There is considerable uncertainty and risk in e-commerce, and trust of online transactions has become an important issue in e-commerce activities (Zhai and Xue 2014), whereas the tendency of trust will influence the evaluation of perceived risk (Zhang and Jiang 2016). It have been proven by some researches that trust tendency has a significant impact on perceived usefulness and perceived ease of use positively through empirical studies, and the tendency of consumers' personal trust also has a positive impact on consumers' trust, in both the network platform and the sellers of the platform (Teo and Liu 2007, Jones and Leonard 2008, Zhang and Jiang 2016, Cui and Ma 2018). A person with a high tendency of trust tends to trust others (Lin et al. 2009). If consumers have a high tendency of trust, their perceived risk level will be reduced (Wu 2014).

\section{Consumer Perceptions-The Reference Of Group}

Social environmental factors of consumers, especially the trust tendency in their most trusted social circle, will directly affect the trust tendency of consumers (Taylor and Todd 1995). This social circle then becomes the reference group that influences consumers' trust tendency. The reference group is a sociological concept describing the group to which people compare and evaluate themselves according to their similar values and behaviors (Hyman 1942). In the process of the gradual acceptance of e-commerce, consumers tend to seek opinions from closely related reference groups.

\section{Perceived Risk - Product Risk}

Consumer delivery risk in the sense of online shopping is closely related to consumer quality as opposed to anticipated goods (Bhatnagar et al, 2000; Jarvenpaa and Todd, 1997; Tan, 1999; Vijayasarathy and Jones, 2000; Forsythe et al, 2006; Torkzadeh and Dillion, 2002) and concerns that the inventory cannot be returned if it does not meet the criteria as expected (Jarvenpaa and Todd, 1997; Vijayasarathy and Jones, 2000). Limitations to online shopping can also increase the risk, as consumers cannot see, touch and feel the product directly (Bhatnagar et al, 2000; Forsythe et al, 2006; Torkzadeh and Dillion, 2002). Moreover, the level of loss risk of a company can varies depending on the type of the product. Common products, such as books and apps, associate with low-risk objects such as consumer goods (Bhatnagar et al, 2000). On the other hand, items such as furniture 
require special precautions to check the quality by handling the product, and therefore furniture products tend to have a higher safety risk, among other product risks.

\section{Perceived Risk - Delivery Risk}

Delayed delivery is one of the main concerns of internet consumer reports (The Hindu, Feb 22, 2010). Since suppliers are often confidential and do not have a specific location or mailing address, it is impossible for consumers to determine the correct means of resolving grievances. In this case, a large number of websites are opened and closed every day, increasing the risk of product delivery (Torkzadeh \& Dillion, 2002).

\section{Perceived Risk - Financial Risk}

Financial risk of online shopping is related to the possibility of losing money while buying in online stores. This risk is most likely not to arise when consumer purchase through offline stores (Bhatnagar et al., 2000). There are different actions which can be viewed as financial risks for consumers, for example when the shop commits fraud (the product is not sent to the consumer or the product purchased by the consumer has a minor flaw, etc.), fraud through a credit card or bank account, then overcharged (Fram and Grady, 1997; Lee, Park and Ahn, 2001; Forsythe et al., 2006). As a result, perceived financial risk tends to be high for some consumers. However, this trend is declining over time because consumers can adjust to online shopping procedures so that they can reduce the risk of losing money during online transactions.

\section{Perceived Risk - Privacy Risk}

Convincing consumers that their personal data is secure is one of the services provided by online stores. Online retailers need to pay more attention to buyers and continue to improve and update their products and services to consumers (Bitner 2000). This concern is linked to the risk of abuse of personal information by unauthorized third parties (Jarvenpaa and Todd, 1996).

\section{Perceived Risk - Convenience Risk}

Comfort Risk is generally defined as a risk related to consumer comfort. For starters, consumers who have experienced frustration or annoyance and may have a bad impression when accessing the Internet to make a purchase. It could be caused by a slow connection, by too many measures to enter the online store, by ambiguous images and limited product descriptions on the site or others. One of the main reasons why consumers make transactions from online stores is to save time, so if the buyer is dissatisfied because the website is not user-friendly, the risk of ease is perceived to be a high risk that can impact the desire to purchase a product. Products at the disposal of consumers at online stores such as competitive product knowledge that is easy to get, the volume of the site is very high, and a greater variety of online items than retail shops allows someone to even want to purchase a product online.

\section{Perceived Benefit - Cost Saving}

Online shopping has been linked to profitability and low prices, as shoppers are able to obtain the same products with same quality at a lower cost due to the cost saved on storage, construction in shops, and decoration that usually incurred by the retail store owners and discharged to the buyers (Miller, 2000). Online shopping helps consumers to gain extensive information on product specifications, locations, endorsement, etc. (Wolfinbarger and Gilly, 2001). In online shopping consumers are allowed to access the information and use it conveniently and efficiently compared to traditional retail stores in "brick and mortar" (Alba et al, 1997; Lynch and Ariely, 2000). Abundant information can be 
collected by consumers directly from the website with a few clicks of the mouse, instead of from the salesperson (Van den Poel and Leunis 1999).

\section{Perceived Benefit - Convenience}

Because the Internet shopping offers a unlimited time of service, space, and weather (Burke, 1997), convenience was proposed by several researchers as perceived benefits of online shopping, due to the more energy and time gained by buying from consumers' own location rather than visiting physical stores (Bhatnagar and Ghosh, 2004; Forsythe et al, 2006; Eastlick and Feinberg, 1999). Online shopping is also identified as a problems-free shopping, i.e. It allows consumers without hesitation to buy anything and just browse the items at their convenience (Forsythe et al, 2006).

\section{Perceived Benefit - Comfort}

Consumers' with a lack of time in shopping experience find that online shopping is more compatible and comfortable, as they can fulfil their needs of personal dan social shopping, by setting a purchasing online from their own location and get the product being delivered at home or other desired place (Dawson et al., 1990). It is important for consumers to feel comfortable in online shopping as another alternative in buying products.

\section{Perceived Benefit - Enjoyment}

The hedonistic motivation to search for pleasure and enjoyment when shopping online (Forsythe et al., 2006) was also associated with online shopping benefits. As consumers search the wide range of any products on the internet, they can also get competitive prices and attractive promotional deals (Jarvenpaa and Todd, 1996).

\section{Perceived Benefit - Selection}

Unlike shopping at brick-and-mortar store, shopping at the internet store can be considered as an innovation of the way to shop. Online shopping gives the flexibility to choose and evaluate products for consumers in different stores. The broad range of items from many different brands and retailers with accessible comprehensive information can be seen as a significant benefit of online shopping to help consumers make choices, which is probably to be an important reason for online shopping (Forsythe et al., 2006; Menon and Kahn, 1995).

\section{Consumer Attitude}

Attitude is known as a feature of knowledge or beliefs that affect the intention of a person to take a specific action (Ajzen 1985, 1991). Research dating from the 1970s investigated the role of attitude in the buying intention (Fishbein and Ajzen, 1975). It is a complex concept described by two factors: the use of the Internet as a shopping venue (Jahng, Jain, and Ramamurthy, 2001) and to the degree that consumers think shopping on a given website is attractive. These variables can be negatively correlated with perceived difficulty in use (Yang et al., 2007). Positive attitudes are needed for consumer buying activity.

\section{Consumer Intention to Buy}

Intention can now be defined as the search of online products to be purchased by using the Internet. It is determined by two factors: the attitude of a person towards a particular behavior and the subjective norms surrounding it (Obeidat, 2014). Furthermore, there is a positive and negative attitude and norms that affected the consumers' intention to buy. It is actually composed of an accumulation of values related to behavioral performance. It is composed of an accumulation of values related to behavioral performance. Contextual 
norms emerging from peers, relatives, teachers and friends take part in shaping an individual's perspective on an event.

As a feasible dependent variable, purchasing intention has become a significant factor in understanding and evaluating online shopping habits. In this situation, with the help of the theory of planned action (Ajzin, 1991), intention becomes a good predictor of actual behavior.

\section{CONCEPTUAL MODEL}

This paper highlights the idea that aspects of perceived risks, perceived benefits and consumer perception should be viewed separately in order to understand its individual contribution to the consumers attitude and consumer purchase intention.

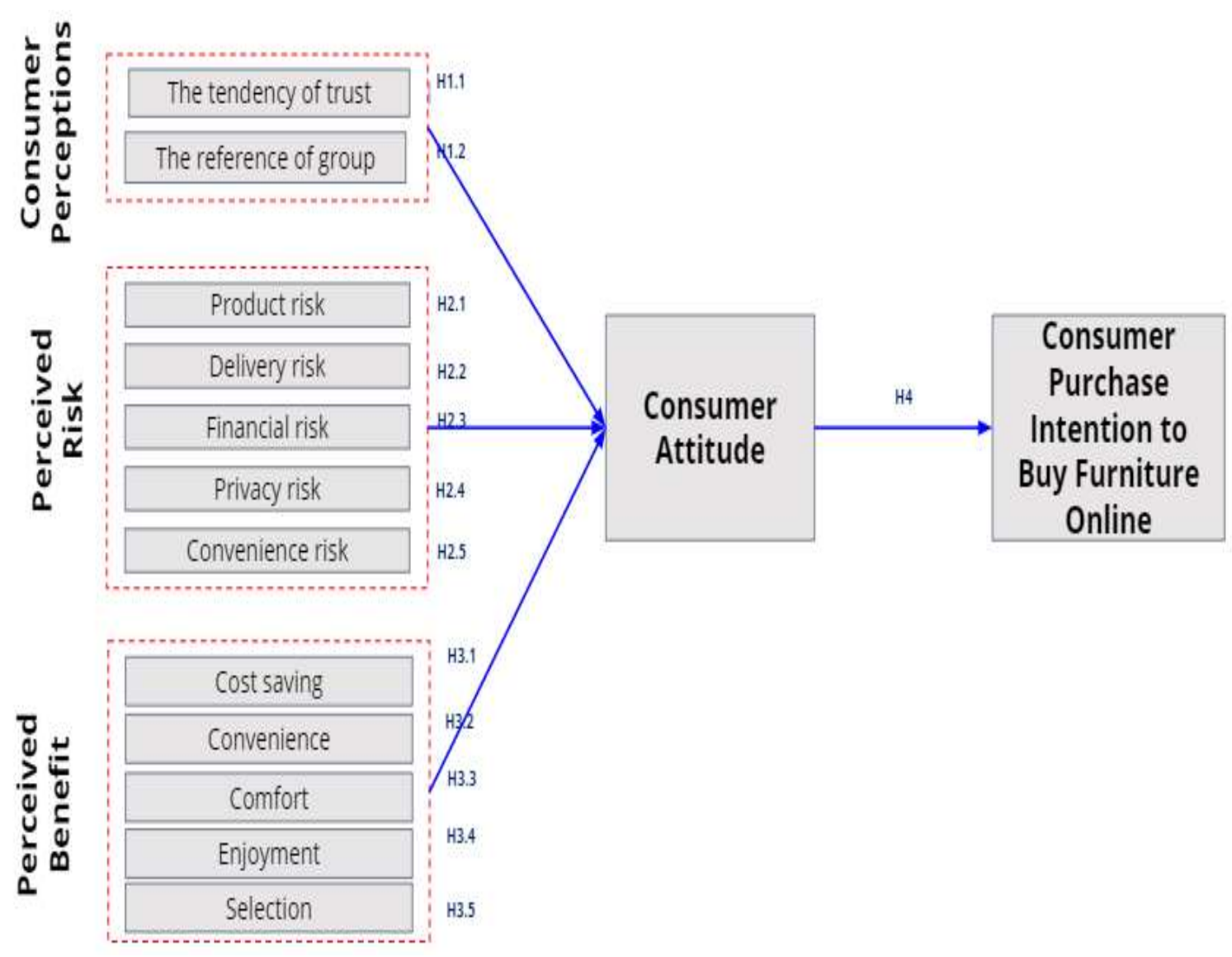

Figure 3. Research Model

H1.1: The Tendency of Trust showed a significant positive relationship to consumer attitude.

H1.2: The Reference of Group showed a significant positive relationship to consumer attitude.

H2.1: Product Risk showed a significant negative relationship to consumer attitude.

H2.3: Delivery Risk showed a significant negative relationship to consumer attitude.

H2.4: Financial Risk showed a significant negative relationship to consumer attitude.

H2.5: Privacy Risk showed a significant negative relationship to consumer attitude.

Jurnal Pemasaran Kompetitif, Vol. 04, No. 1, Oktober 2020 
H2.6: Convenience Risk showed a significant negative relationship to consumer attitude.

H3.1: Cost Saving showed a significant positive relationship to consumer attitude.

H3.2: Convenience showed a significant positive relationship to consumer attitude.

H3.3: Comfort showed a significant positive relationship to consumer attitude.

H3.4: Enjoyment showed a significant positive relationship to consumer attitude.

H3.5: Selection showed a significant positive relationship to consumer attitude.

H4 : Consumer Attitude showed a significant positive relationship to consumer intention to purchase furniture online.

\section{METHODOLOGY}

The internet-administered survey was selected to perform simple random sampling near Greater Jakarta (Jakarta, Bogor, Depok, Tangerang, Bekasi), the questionnaire contained 45 questions in five sections. Five portions of the questionnaire included 45 questions. Demographic variables are arranged in part one (six questions) as important factors which cannot be ignored, including gender, age, occupation, level of education, monthly income and city of origin. The second part is related to Consumer Perception, 3 items were related to trust and 3 items on their perceptions of peer influence. On the third part were 14 items which evaluate perceived risk and 13 items to evaluate perceived benefit on buying furniture online. The third part is to evaluate consumer attitude with 2 items and on the last part were 4 items intended to evaluate consumer purchase intention.

The target population of this research is people living in the Greater Jakarta area (Jakarta, Bogor, Depok, Tangerang, Bogor). The questionnaire was distributed by random sampling to people who lived and owned a house or apartment in Greater Jakarta area (Jakarta, Bogor, Depok, Tangerang, Bogor), who have made a furniture purchase, either by online or offline purchase. However, only 321 data were used and valid in data analysis process. The questionnaires were written using Bahasa language and submitted online using google form tools.

\section{E. RESULTS}

\section{Profile of Respondents}

Of 343 questionnaires collected, 321 were valid, because we only targeted the citizen in Greater Jakarta. We also examine the personal demographic information, such as gender, age, educational level, employer, average monthly income, and region. Table 1 gives information about the results of frequency and percentage of responses. The majority of respondents were female (53.3\%), although it seems almost balanced between male and female. $48 \%$ of respondents are between the ages of $26-35$, while this middle age group are more interested in technology. Regarding to the middle age group, the majority of the respondents have finished their undergraduate study $(66,7 \%)$ and work in private sectors (73,5\%, with monthly average income of Rp 5-10 million per month (34,6\%) and Rp 10-20 million per months (32,4\%). All valid respondents are living in Greater Jakarta area, because this study examine the variables of buying furniture online in Greater Jakarta area only. 
Table 1. Profile Respondent

\begin{tabular}{|l|l|c|c|}
\hline \multicolumn{1}{|c|}{ Variable } & \multicolumn{1}{|c|}{ Description } & Frequency & Percentage \\
\hline & Male & 150 & $46,7 \%$ \\
\hline & Female & 171 & $43,9 \%$ \\
\hline & $18-25$ Year & 38 & $11,8 \%$ \\
\hline & $26-35$ Year & 154 & $48,0 \%$ \\
\hline & 36 - 40 Year & 34 & $10,6 \%$ \\
\hline Educational Level & $>40$ Year & 95 & $29,6 \%$ \\
\hline & High School & 7 & $2,2 \%$ \\
\hline & Undergraduate & 214 & $66,7 \%$ \\
\hline & Graduate & 82 & $25,5 \%$ \\
\hline Employer & Postgraduate & 4 & $1,2 \%$ \\
\hline & Others & 14 & $4,4 \%$ \\
\hline & Private Employee & 236 & $73,5 \%$ \\
\hline & Civil Servant & 25 & $7,8 \%$ \\
\hline Monthly Average Income & Entrepreneur & 35 & $10,9 \%$ \\
\hline & Others & 25 & $7,8 \%$ \\
\hline & Rp 5 Million & 39 & $12,1 \%$ \\
\hline & Rp 10 - 20 Million & 111 & $34,6 \%$ \\
\hline Region & $>$ Rp 20 Million & 104 & $32,4 \%$ \\
\hline & Jabodetabek & 321 & $100,0 \%$ \\
\hline
\end{tabular}

\section{Data Analysis (Reliability and Factor Analyses)}

The reliability analysis on this journal were tested by way of calculating the value of Cronbach Alpha using SPSS software to determine the consistency of a test or a scale. The accepted Cronbach Alpha value is amounting at scale 0.70 (Christmann and Van Aelst, 2005) which indicates an acceptable level of reliability. Following Table 2. below, this study shows that only 2 variables (financial risk $\alpha 0.521$ and privacy risk $\alpha 0.652$ ) from Perceived Risk and 1 variable (convenience $\alpha$ 0.644) from Perceived Benefit had a scale below 0.70 . Therefore, most of different variables on this study shall be deemed to have a good reliability indication.

Aside than that, on the factor analysis, value which scale less than 0.30 shall be eliminated from the variable. The main purpose of the factor analysis conducted was to identify the correlation between the variables and its factors (factor loading). None of below factor loading were eliminated as all of the value scale above than 0.30 .

Therefore, as the Cronbach alpha indicate a good reliability indication and none of the factor loading need to be eliminated, we continue to maintain the list of questionnaires as shown in Table 2.

Following above, we also perform KMO and Bartlett's test on the basis to measure the adequacy sampling for conducting factor analysis. The KMO result of this study has met the expected value of KMO which shall be above 0.50. 
Table 2. Factor Analysis

\begin{tabular}{|c|c|c|c|c|c|}
\hline \multicolumn{2}{|c|}{ Factor Analysis } & \multirow{2}{*}{$\begin{array}{l}\text { Factor } \\
\text { Loading }\end{array}$} & \multirow{2}{*}{$\begin{array}{l}\text { Explained } \\
\text { Variance }\end{array}$} & \multirow[t]{2}{*}{ KMO } & \multirow{2}{*}{$\begin{array}{c}\text { Cronbach } \\
\text { Alpha }\end{array}$} \\
\hline \multirow{8}{*}{$\begin{array}{l}\text { Consumer } \\
\text { Perception }\end{array}$} & Tendency of Trust & & & & \\
\hline & $\begin{array}{l}\text { Family and People around } \\
\text { think that buying furniture } \\
\text { online is a good choice }\end{array}$ & .862 & 78.862 & .694 & .865 \\
\hline & $\begin{array}{l}\text { Most people who have } \\
\text { purchased furniture online } \\
\text { thought it better }\end{array}$ & .929 & & & \\
\hline & $\begin{array}{l}\text { Family and People around } \\
\text { are not opposed to buying } \\
\text { furniture online }\end{array}$ & .871 & & & \\
\hline & The reference Group & & & & \\
\hline & $\begin{array}{l}\text { Even if I don't know the } \\
\text { person, I am willing to } \\
\text { believe his opinion }\end{array}$ & .840 & 64.504 & .619 & .723 \\
\hline & I easily trust others & .873 & & & \\
\hline & $\begin{array}{l}\text { I think most people are } \\
\text { sincere and kind }\end{array}$ & .684 & & & \\
\hline \multirow[t]{13}{*}{$\begin{array}{l}\text { Perceived } \\
\text { Risk }\end{array}$} & $\begin{array}{l}\text { Product Performance } \\
\text { Risk }\end{array}$ & & & & \\
\hline & $\begin{array}{l}\text { I can't examine the actual } \\
\text { product }\end{array}$ & .740 & 61.504 & .811 & .841 \\
\hline & $\begin{array}{l}\text { In online shopping I will } \\
\text { have to pay for shipping } \\
\text { and handling }\end{array}$ & .825 & & & \\
\hline & $\begin{array}{l}\text { I will have to wait for } \\
\text { merchandise to be } \\
\text { delivered }\end{array}$ & .836 & & & \\
\hline & $\begin{array}{l}\text { It is difficult to judge quality } \\
\text { of products in online } \\
\text { shopping }\end{array}$ & .757 & & & \\
\hline & $\begin{array}{l}\text { There is no money back } \\
\text { guarantee for products } \\
\text { purchased from online } \\
\text { medium }\end{array}$ & .759 & & & \\
\hline & Delivery Risk & & & & \\
\hline & $\begin{array}{l}\text { I am concerned that online } \\
\text { shops may not deliver the } \\
\text { same item I ordered }\end{array}$ & .737 & 65.913 & .658 & .737 \\
\hline & $\begin{array}{l}\text { It is hard to return a } \\
\text { product purchased through } \\
\text { an online store }\end{array}$ & .841 & & & \\
\hline & $\begin{array}{l}\text { I may receive a defective } \\
\text { product in online shopping. }\end{array}$ & .852 & & & \\
\hline & Financial Risk & & & & \\
\hline & $\begin{array}{l}\text { I think in online shopping, I } \\
\text { might get overcharged. }\end{array}$ & .822 & 67.624 & .500 & .521 \\
\hline & Providing credit card & .822 & & & \\
\hline
\end{tabular}


ISSN NO. (PRINT) 2598-0823, (ONLINE) 2598-2893

Factor Analysis
Factor Loading

Explained Variance

KMO Cronbach Alpha

\begin{tabular}{|c|c|c|c|c|c|}
\hline & \multicolumn{5}{|l|}{$\begin{array}{l}\text { information through the } \\
\text { web is risky }\end{array}$} \\
\hline & \multicolumn{5}{|l|}{ Privacy risk } \\
\hline & $\begin{array}{l}\text { My personal information } \\
\text { may not be kept. }\end{array}$ & .861 & 74.197 & .500 & .652 \\
\hline & $\begin{array}{l}\text { I worry about the reliability } \\
\text { of internet retailers }\end{array}$ & .861 & & & \\
\hline & \multicolumn{5}{|l|}{ Convenience Risk } \\
\hline & $\begin{array}{l}\text { I find it too complicated to } \\
\text { place order online }\end{array}$ & .921 & 84.892 & .500 & .822 \\
\hline & $\begin{array}{l}\text { Pictures of the products } \\
\text { take too long to come up }\end{array}$ & .921 & & & \\
\hline \multirow{18}{*}{$\begin{array}{l}\text { Perceived } \\
\text { Benefit }\end{array}$} & \multicolumn{5}{|l|}{ Cost Saving } \\
\hline & $\begin{array}{l}\text { Discounts sale and free } \\
\text { gifts are available in online } \\
\text { shopping }\end{array}$ & .799 & 73.972 & .637 & .824 \\
\hline & $\begin{array}{l}\text { Internet shopping provides } \\
\text { best price }\end{array}$ & .924 & & & \\
\hline & $\begin{array}{l}\text { Online stores save my } \\
\text { money }\end{array}$ & .852 & & & \\
\hline & \multicolumn{5}{|l|}{ Convenience } \\
\hline & $\begin{array}{l}\text { I don't get any busy signal } \\
\text { when trying to accessing } \\
\text { online store }\end{array}$ & .491 & 49.312 & .640 & .644 \\
\hline & $\begin{array}{l}\text { I can save the effort of } \\
\text { visiting stores }\end{array}$ & .815 & & & \\
\hline & $\begin{array}{l}\text { In online shops I don't } \\
\text { have to face embarrassed } \\
\text { if I don't make a purchase. }\end{array}$ & .769 & & & \\
\hline & $\begin{array}{l}\text { I can avoid the hassles of } \\
\text { driving and parking }\end{array}$ & .691 & & & \\
\hline & \multicolumn{5}{|l|}{ Comfort } \\
\hline & $\begin{array}{l}\text { I can shop in privacy of } \\
\text { home }\end{array}$ & .903 & 81.599 & .500 & .771 \\
\hline & I don't have to leave home & .903 & & & \\
\hline & \multicolumn{5}{|l|}{ Enjoyment } \\
\hline & $\begin{array}{l}\text { Through online shopping I } \\
\text { can access many brands } \\
\text { and retailers }\end{array}$ & .837 & .66 .846 & .660 & .748 \\
\hline & $\begin{array}{l}\text { It is exciting to receive a } \\
\text { package }\end{array}$ & .863 & & & \\
\hline & $\begin{array}{l}\text { Online shops allow me to } \\
\text { custom design a product }\end{array}$ & .748 & & & \\
\hline & Selection & & & & \\
\hline & $\begin{array}{l}\text { Online shopping provides } \\
\text { me with broader selection } \\
\text { of products }\end{array}$ & & & & \\
\hline
\end{tabular}


ISSN NO. (PRINT) 2598-0823, (ONLINE) 2598-2893

\begin{tabular}{|c|c|c|c|c|c|}
\hline \multicolumn{2}{|c|}{ Factor Analysis } & \multirow{2}{*}{$\begin{array}{l}\begin{array}{c}\text { Factor } \\
\text { Loading }\end{array} \\
.909\end{array}$} & \multirow{2}{*}{$\begin{array}{l}\text { Explained } \\
\text { Variance }\end{array}$} & \multirow{2}{*}{$\begin{array}{l}\text { KMO } \\
.500\end{array}$} & \multirow{2}{*}{$\begin{array}{l}\begin{array}{c}\text { Cronbach } \\
\text { Alpha }\end{array} \\
.788\end{array}$} \\
\hline ttitude & $\begin{array}{l}\text { Buying furniture from the } \\
\text { internet is a good idea }\end{array}$ & & & & \\
\hline & $\begin{array}{l}\text { I am willing to go to the } \\
\text { online website to buy } \\
\text { furniture }\end{array}$ & .909 & & & \\
\hline \multirow{5}{*}{$\begin{array}{l}\text { Donsumer } \\
\text { urchase } \\
\text { ntention to } \\
\text { uy } \\
\text { urniture } \\
\text { nline }\end{array}$} & Intention to Buy & & & & \\
\hline & $\begin{array}{l}\text { will keep using online } \\
\text { store(s) in the future for } \\
\text { buying }\end{array}$ & .677 & 62.535 & .710 & .792 \\
\hline & $\begin{array}{l}\text { I will use online store(s) on } \\
\text { a regular basis in the future } \\
\text { for buying }\end{array}$ & .907 & & & \\
\hline & $\begin{array}{l}\text { I will frequently use online } \\
\text { store(s) in the future for } \\
\text { buying }\end{array}$ & .897 & & & \\
\hline & $\begin{array}{l}\text { I will use my preferred site } \\
\text { rather than other Websites } \\
\text { for purchasing product(s) }\end{array}$ & .645 & & & \\
\hline
\end{tabular}

Source: Primary Data (2020)

\section{The Descriptive Statistic}

The descriptive analysis is performed to assess the characteristic the data and also to find certain pattern on the data. On this analysis, the frequency of data, mean, and standard deviation are sought through the use of statistical software. The mean level of 3.00 was used as an average scale (five - point Likert scale) in this research. All of the variables have the average score mean level ranging from 3.45 to 3.97. It shall be deemed that most of the respondents were agree with all the constructs shown in Table 3 . In addition to that, it is shown the positive relationship between attitude and the consumer intention to purchase furniture online.

Table 3. Descriptive Analysis

\section{Descriptive Statistics}

\begin{tabular}{l|l|l|l|l|l} 
& N & Minimum & Maximum & Mean & Std. Deviation \\
\hline Tendency_of_trust & 321 & 1.00 & 5.00 & 3.5504 & .95687 \\
\hline The_Reference_Group & 321 & 1.00 & 5.00 & 3.4569 & .83268 \\
\hline $\begin{array}{l}\text { Product_Performance_Ri } \\
\text { sk }\end{array}$ & 321 & 1.00 & 5.00 & 3.8766 & .77265 \\
\hline Delivery_Risk & 321 & 1.33 & 5.00 & 3.6999 & .77657 \\
\hline Financial_Risk & 321 & 1.00 & 5.00 & 3.5187 & .79232 \\
\hline Privacy_Risk & 321 & 1.50 & 5.00 & 3.9782 & .78928 \\
\hline Convenience_Risk & 321 & 1.00 & 5.00 & 3.5312 & .99403 \\
\hline Cost_Saving & 321 & 1.00 & 5.00 & 3.6895 \\
\hline Convenience & 321 & 1.00 & 5.00 & 3.7671 & .84789 \\
\hline Comfort & 321 & 1.00 & 5.00 & 3.7991 \\
\hline Enjoyment & 321 & 1.00 & 5.00 & 3.8380 \\
\hline Selection & 321 & 1.00 & 5.00 & 3.5732 \\
\hline Attitude & 321 & 1.00 & 5.00 & 3.6324 \\
\hline Intention_to_Buy & 321 & 1.00 & 5.00 & 3.5467 \\
\hline Valid N (listwise) & 321 & & & .87819 \\
\hline
\end{tabular}




\section{Multiple Regression Analysis}

Pursuant to research model shown in Figure 3 and in order to discover the relation between all the constructs which impact toward one another, a series of multiple regressions was performed to identify and discover the relation between each independent variables' variance on the dependent variable. The dependent variable in this research is attitude, meanwhile the independent variables are consumer perception (tendency of trust, and the reference of group), perceived risk (product risk, delivery risk, financial risk, privacy risk, convenience risk) and perceived benefits (cost saving, convenience, comfort, enjoyment, selection).Overall, the multiple regression analysis was performed 13 times for each independent variable.

On the consumer perception construct showed that tendency of trust $(\boldsymbol{\beta}=.349)$ and the reference group $(\boldsymbol{\beta}=.262)$ have a positive influence on attitude (sig 0.00$)$. The result supported the hypotheses of $\mathrm{H} 1$. Thus, this result supported the hypotheses $\mathrm{H} 1$ as shown in Table 4.

\section{Table 4. Consumer Perception Constructs}

Consumer Attitude as dependent variable

\begin{tabular}{|l|l|l|c|c|c|c|c|}
\hline & R square & $\begin{array}{c}\text { Adjusted } \\
\text { R Square }\end{array}$ & $\begin{array}{c}\text { Standardized } \\
\text { Coefficient (Beta) }\end{array}$ & sig & Result \\
\hline Tendency of Trust & .122 & .119 & .349 & 6.658 & .000 & Supported \\
\hline The reference Group & 0.69 & 0.66 & .262 & 4.850 & .000 & Supported \\
\hline
\end{tabular}

Following that, on the perceived risk construct, all hypotheses of product performance risk $(\mathrm{H} 2.1)$, delivery risk $(\mathrm{H} 2.2)$, financial risk $(\mathrm{H} 2.3)$, privacy risk $(\mathrm{H} 2.4)$, convenience risk (H2.5) showed negative influence on attitude ( $\mathrm{sig}>0.05$ ), therefore these result was not supported hypotheses of $\mathrm{H} 2$ and further rejected. Thus, this result not supported the hypotheses $\mathrm{H} 2$ as shown in Table 5.

Table 5. Perceived Risk Constructs

\section{Consumer Attitude as dependent variable}

\begin{tabular}{|l|c|c|c|c|c|c|}
\hline & R square & $\begin{array}{c}\text { Adjusted } \\
\text { R Square }\end{array}$ & $\begin{array}{c}\text { Standardized } \\
\text { Coefficient (Beta) }\end{array}$ & $\mathbf{t}$ & sig & Result \\
\hline Product performance risk & 0.01 & -.002 & 0.34 & .612 & .541 & Not Supported \\
\hline Delivery Risk & .001 & -.002 & -.034 & -.603 & .547 & Not Supported \\
\hline Financial Risk & .002 & -.002 & 0.40 & .718 & .473 & Not Supported \\
\hline Privacy risk & .001 & -.002 & -.034 & -.613 & .540 & Not Supported \\
\hline Convenience Risk & .002 & -.001 & .045 & .804 & .422 & Not Supported \\
\hline
\end{tabular}

The latest construct using consumer attitude as dependent variable were perceived benefits, all of the variables of perceived benefit had a positive significant relationship with the consumer attitude as the dependent variable $(\mathrm{sig}<0.05)$. Thus, this result supported the hypotheses $\mathrm{H} 3$ as shown in Table 6.

Table 6. Perceived Benefit Construct

Consumer Attitude as dependent variable

\begin{tabular}{|l|c|c|c|c|c|c|}
\hline & R square & $\begin{array}{c}\text { Adjusted } \\
\text { RSquare }\end{array}$ & $\begin{array}{c}\text { Standardized } \\
\text { Coefficient (Beta) }\end{array}$ & t & sig & Result \\
\hline Cost Saving & .082 & .080 & .287 & 5.353 & .000 & Supported \\
\hline Convenience & .179 & .177 & .423 & 8.349 & .000 & Supported \\
\hline Comfort & .253 & .251 & .503 & 10.406 & .000 & Supported \\
\hline Enjoyment & .105 & .102 & .324 & 6.110 & .000 & Supported \\
\hline Selection & 0.58 & 0.55 & .241 & 4.437 & .000 & Supported \\
\hline
\end{tabular}


On the test of consumer intention as dependent variable, the attitude had a positive significant relationship towards the consumer intention to purchase furniture online. Thus, this result supported the hypotheses $\mathrm{H} 4$ as shown in Table 7.

Table 7. Consumer Attitude Construct

\begin{tabular}{|l|c|c|c|c|c|c|}
\hline \multicolumn{8}{|c|}{ Consumer intention to purchase furniture online as dependent variable } \\
\hline Attitude & R square & Adjusted & Standardized & $\mathbf{t}$ & sig & Result \\
\hline .318 & .316 & .564 & 12.199 & .000 & Supported \\
\hline
\end{tabular}

Overall the results indicate that $\mathrm{H} 1$ (Consumer Perception) and $\mathrm{H} 3$ (Perceived Benefit) variables are positively affecting Consumer Attitude $(\mathrm{H} 4)$ therefore it is also affecting the Consumer Intention to purchase furniture online. On the other hand, H2 (Perceived Risk) had a negative relationship towards the Consumer Attitude to purchase furniture online. Thus, $\mathrm{H} 2$ was not supported.

\section{Discussion}

The purpose of this study was to examine factors that consider can affect the consumer intention to purchase furniture via online. The factors defined in this study are consumer perception, perceived risk, perceived benefit and consumer attitude. The result in this study as elaborated above showed that out of the 4 (four) factors, only 3 factors that had a significant relationship, 2 factors had a positive relationship towards consumer attitude and 1 factor had a positive relationship towards the consumer intention to purchase furniture online.

The first factor that had a positive relationship towards consumer attitude is consumer perception which supported by two variables, the tendency of trust and the reference group. Following this study, it is proven that consumers will tend to have more trust and confidence to purchase something through online store, if they have received a reference or good review from their circle, whether it's their family, friends or colleagues. This was supported by the result of this study where the tendency of trust explained $78 \%$ of the total variance where the reference group explained $64 \%$ of the total variance of this study.

The second factor that had a positive relationship is a perceived benefit, where perceived benefit has five variables and each of the variables shows a positive relationship towards the consumer attitude. Each of the variables are cost saving, convenience, comfort, enjoyment and selection. This study indicates that generally every benefit received by the consumer when making a purchase of furniture online will likely affect the consumer attitude. This was supported by the result where the most important concern that consumer have is comfort explained $81 \%$ of the total variance and the second most important is cost saving where explained $73 \%$ of the total variance, where others stands as enjoyment explained $66 \%$, convenience explained $49 \%$, selection variables has no percentage of the total variance as the sole variable. Therefore, to sum up, many of the consumers are attracted to the discount or promo on online purchase, or the wholesome experience felt by the consumer, the simplicity website and others experience that will impress the consumer. When a consumer feels content and has a pleased experience accessing the online purchase, it will affect the consumer attitude to repurchase via online without hesitation.

The third factor is perceived risk which had a negative relationship towards the consumer attitude. The perceived risk variables are product performance risk, delivery risk, financial risk, privacy risk, convenience risk. The first important factor is convenience risk where consist of $84 \%$ of the total variance and the second important factor is privacy risk $74 \%$ of the total variance, where financial risk $67 \%$, delivery risk $65 \%$, product performance risk $61 \%$ of the total variance. In this study many consumers didn't see a risk as a negative 
impact to purchase furniture online, they will buy as long as the benefit is greater and some groups refer to it.

The fourth factor is consumer attitude which had a positive relationship towards the consumer intention and had $82 \%$ of the total variance. This study shows that consumer attitude had a correlation to increase consumer intention to purchase furniture online.

To sum up, following the data analysis conducted towards the Internet-administered survey method that we used in Greater Jakarta, the result shows that consumers in Greater Jakarta will make a purchase action if they believe that the advantage, they received is greater than the risk that may arise. It is verified by the result which shows that only the perceived risk factors (H2) is not supported this study.

\section{Managerial Implications}

This study can be used by future marketers particularly in the furniture industry and intend to expand and develop their business and generate more sales using online furniture stores in the Greater Jakarta area. This study examined the factors that considered will affect the consumer attitude and intention. By way of analyzing this study hopefully will help the company to create a strategy to focus mitigate such risk that might affect the consumer intention to purchase furniture online. Therefore, the company may have the services and can provide pleasant experience for every consumer that visits their website. Additionally, this study can increase more sales on furniture industry in Greater Jakarta.

\section{F. CONCLUSIONS}

This study had several limitations that can be reviewed for future research. The first limitation is this study only using an internet-administered questionnaire to collect the data and not performing further interviews to verify the data authenticity. Thus, future research can consider performing further interviews in order to obtain another factor or another aspect that is not seen by this study. The second limitation is the demographic area where this study is only conducted in the Greater Jakarta area. The future research can consider conducting the research in greater area than this study, for example in all area in Indonesia. 


\section{REFERENCES}

Alba J, Lynch J, Wood S, et al. (1997). "Interactive Home Shopping: Consumer, Retailer, and Manufacturers Incentives to Participate in Electronic Marketplaces". Journal of Marketing Vol:61. No.3, pp. 38-53.

Ajzen, I. 1985. From intentions to actions: A theory of planned behavior. In: Action Control: From Cognition to Behavior. J. Kuhl and J. Beckman (Eds.). Springer, Heidelberg, Germany. pp. 11-39.

Ajzen, I. 1991. The theory of planned behavior. Organ. Behav. Hum. Decis. Process. $50(2): 179-211$.

Ajzen, I. and M. Fishbein. 1980. Understanding Attitudes and Predicting Social Behavior: An Illustration of Applied Social Research. Prentice Hall, Englewood Cliffs, New Jersey.

Bhatnagar, A. \& Ghose, S. (2004). Segmenting consum- ers based on the benefits and risks of Internet shopping. Journal of Business Research, 57(12), 1352-1360.

Bhatnagar, A., Misra, S. \& Rao, H. R. (2000). On risk, convenience and Internet shopping behavior. Communication of the ACM, 43(11), 98-105.

Burke, R. R. (1997). Do you see what I see? The future of virtual shopping. Journal of the Academy of Marketing Science, 25(4), 352-361.

Christmann A. \& van Aelst, S. (2005), "Robust Estimation of Cronbach's Alpha", Elsevier Science, 1-25

Cronbach, L. J. 1951. Coefficient alpha and the internal structure of tests. Psychometrika 1951(16):297-334.

Cui, R. and Y. C. Ma. 2018. Effect of credit service mechanisms on consumers' purchase intention in online transaction platform. J. Jiangsu Univ. (Social Sci. Ed.) 20(3):74-83. (In Chinese.).

Eastlick, M. \& Feinberg, R. (1999). Shopping motives for mail catalog shopping. Journal of Business Research, 45(3), 281-290.

Emarketer (2018), Consumers' Warming Up to Purchasing Furniture Online, Available from https://www.emarketer.com/content/consumers-are-warming-up-to-purchasing-furnitureonline/

Fishbein, M. and I. Ajzen. 1975. Belief, Attitude, Intention and Behaviour: An Introduction to Theory and Research. Addison-Wesley, Reading, Massachusetts.

Forsythe, S., Liu, C., Shannon, D. \& Gardner, L. C. (2006). Development of a scale to measure the per- ceived benefits and risks of online shopping. Journal of Interactive Marketing, 20(2), 55-75.

Forsythe, S. M. \& Shi, B. (2003). Consumer patronage and risk perceptions in Internet shopping. Journal of Business Research, 56(11), 867-875.

Fram, E. H. \& Grady, D. B. (1997). Internet shoppers: Is there a surfer gender gap? Direct Marketing, 59(9), 46-50.
Global Business Indonesia Article 2018, http://www.gbgindonesia.com/en/manufacturing/article/2018/indonesia s furniture indu stry competitive advantages hampered by bureaucracy 11859.php


George, J. F. (2004). The theory of planned behavior and Internet purchasing. Journal of Internet Research. 14(3).198-212. Available at http://dx.doi.org/10.1108/10662240410542634

Ghosh, S. (1998). Marketing business sense of the inter- net. Harvard Business Review, March-April, 26(2), 127-135.

Husain, T., \& Sunardi, N. (2020). Firm's Value Prediction Based on Profitability Ratios and Dividend Policy. Finance \& Economics Review, 2(2), 13-2

Hassan, A. M., Kunz, M. B., Pearson, A. W. \& Mohamed, F. A. (2006). Conceptualization and measurement of perceived risk in online shopping. The Marketing Management Journal, 16(1), 138-147.

IAMAI (Internet and Mobile Association of India) Annual report 2012-2013, available at http://www.iamai.in/pdf/AnnualReport201314LowRes.pdf

Jahng, J., Jain, H., \& Ramamurthy, K. (2001).The impact of electronic commerce environment on user behavior. E-service Journal, 1(1), 41-53.

Jarvenpaa, S. L. \& Todd, P. A. (1996). Consumer reac- tion to electronic shopping on the world wide web. International Journal of Electronic Commerce, 1(2), 59-88.

Jones, K. and L. N. K. Leonard. 2008. Trust in consumer-to-consumer electronic commerce. Inform. Manag. 45(2):88-95.

Keeney, R. L. (1999). The value of internet commerce to the Customer. Management Science, 45(4), 533-545.

Krista Gracia (2018), Article, https://www.emarketer.com/content/consumers-are-warmingup-to-purchasing-furniture-online

Kadim, A., Sunardi, N., \& Husain, T. (2020). The modeling firm's value based on financial ratios, intellectual capital and dividend policy. Accounting, 6(5), 859-870.

Lee, D., Park J. \& Ahn, J. (2001). On the Explanation of Factors Affecting E-Commerce Adoption. Proceedings of the 22nd Information Conference on Information Systems (pp. 109-120). New Orleans, LA.

Lesmana, R. (2017). Pengaruh Citra Perusahaan Terhadap Keputusan Pembelian Konsumen PT. Garuda Indonesia Tbk.(Persero). JIMF (Jurnal IImiah Manajemen Forkamma), 1(1).

Lesmana, R. (2019). Pengaruh Kualitas Produk Dan Kualitas Pelayanan Terhadap Kepuasan Konsumen Pt. Radekatama Piranti Nusa. Jurnal Pemasaran Kompetitif, 2(2), 115-129.

$\mathrm{Li}, \mathrm{P} .2007$. Analysis of influence on the online shopping attitude in $\mathrm{C} 2 \mathrm{C}$ e-commerce. Dissertation. Harbin Institute of Technology, China. (In Chinese.).Lim, Weng Marc; Ting, Ding Hooi (2014), "Consumer Acceptance and Continuance of Online Group Buying", The Journal of Computer Information Systems, 87-96.

Lim, J. S., Darley, W. \& Summers, J. O. (1994). An as- sessment of country of origin effects under alterna- tive presentation format. Journal of the Academy of Marketing Science, 22(3), 274-182.

Lim, N. (2003). Consumers' perceived risk: Sources ver- sus consequences. Electronic Commerce Research and Applications, 2(3), 216-228. 
Lin, J. B., Y. W. Lu, and J. L. Zhang. 2009. An empirical study on consumers' trust of mobile stock based on TAM theory. J. Manag. Sci. 22(5):61-71. (In Chinese).

Lin, Meng, et al. (2019), "Research on Consumers' Attitude in China about Using Online-toOffline

Lutz, R. J. (1991). The role of attitude theory in marketing. In H. H. Kassarjian \& T. S. Roberson (Eds), Perspectives in consumer behavior (pp. 317-339). Englewood Cliffs, New Jersey: Prentice Hall.

Lynch, J. G. \& Ariely, D. (2000). Wine online: Search costs affect competition on price, quality and distribu- tion. Journal of MarketingScience,19(1), 83-103.

Malhotra, N. K., Kim, S. S., \& Agarwal, J. (2004). Internet users' information privacy concerns (IUIPC): The construct, the scale, and a causal model. Information Systems Research, 15(4), 336-355. Retrieved from http://isr.journal.informs.org/content/15/4/336

Malls Going to the Wall as Internet Shopping becomes More Popular. (2011). Retrieved from: http://www.news.com.au/business/malls-going-to-the-wallas-internet-shopping-becomes-more-popular/story-e6frf-m1i-1226075407253

Marganosky, M. A. \& Cude, B. J. (2000). Consumer response to online grocery shopping. International Journal of Retail and Distribution Management, 28(1), 17-26.

Miller, N. G. (2000). Retail leasing in a web enabled world. Journal of Real Estate Portfolio Management, 6(2), 167-184.

Mode for Purchasing Wooden Furniture", Forest Product Journal Vol. 69 No. 2, 159-172.

Mordor Intelligence, https://www.mordorintelligence.com/industry-reports/indonesia-homefurniture-market?gclid=CjwKCAiAxMLvBRBNEiwAKhr-nAAhU OpHbrwOUP97VZPPLxaXPaDbMfANiCwLgAHTb9tbHmEUx txoC8gQQAvD BwE

Mordor Intelligence (2019), Indonesia Home Furniture Market - Growth, Trends, and Forecast (2019-2024), Available from https://www.mordorintelligence.com/industryreports/indonesia-home-furniture-market/

Resnick, P., Zeckhauser, R., Friedman, E. \& Kuwabara, K. (2000). Reputation Systems. Communications of the ACM, 43(12), 45-48.

Sarwani, S., Sunardi, N., AM, E. N., Marjohan, M., \& Hamsinah, H. (2020). Penerapan IImu Manajemen dalam Pengembangan Agroindustri Biogas dari Limbah Kotoran Sapi yang Berdampak pada Kesejahtraan Masyarakat Desa Sindanglaya Kec. Tanjungsiang, Kab. Subang. Jurnal Abdi Masyarakat Humanis, 1(2).

Rotter, J. B. 1971. Generalized expectancies for interpersonal trust. Am. Psychol. 26(5):443-452.

Sinha, Priyanka; Singh, Saumya (2016), "E-Retailing in Developing Economy - A Study on Consumers' Perceptions", Academy of Marketing Studies Journal Volume 20, Number $3,62-72$.

Statista (2019), Number of internet users in Indonesia from 2017 to 2023 (in millions), Available from https://www.statista.com/statistics/254456/number-of-internet-users-inindonesia/

Swinyard, W. R., \& Smith, S. M. (2003). Why People Don't Shop Online: A Lifestyle Study of the Internet Consumers. Psychology and Marketing, 20(7). 567-597. http://dx.doi.org/10.1002/mar.10087/ 
Taylor, S. and P. A. Todd. 1995. Understanding information technology usage: A test of competing models. Inform. Syst. Res. 6(2):144-176.

Teo, T. S. H. and J. Liu. 2007. Consumer trust in e-commerce in the United States, Singapore and China. Omega 35(1):22-38.

Torkzadeh, G. \& Dillion, G. (2002). Measuring fac- tors that influence the success of internet commerce. Information Systems Research, 13(2), 187-204.

Van den Poel, D. \& Leunis, J. (1999). Consumer ac- ceptance of the Internet as a channel of distribution. Journal of Business Research, 45(3), 249-256.

Verhoef, P.C. \& Langerak, F. (2001) Possible determi- nants of consumers' adoption of electronic grocery shopping in The Netherlands, Journal of Retailing and Consumer Services, 8, 275-85.

Vijayasarathy, L. R. \& Jones, J. M. (2000). Print and in- ternet catalog shopping: Assessing attitudes and inten- tions. Internet Research, 10(3), 191-202.

Vijayasarathy, L. R. (2004). Predicting consumer inten- tions to use on-line shopping: The case for an aug- mented technology acceptance model. Information Management, 41(6), 747-762.

Wani, Sajid Nazir; Malik, Sheeba (2013), "A Comparative Study of Online Shopping Behaviour: Effects of Perceived Risks and Benefit", International Journal of Marketing and Business Communication Volume 2, 41-55.

Williams E.S, Konrad T.R, Scheckler WE, et al. (2001), "Understanding physicians' intentions to withdraw from practice: the role of job satisfaction, job stress, mental and physical health", Health Care Manage Rev 26, 7-19.

Wolfinbarger, M. F. \& Gilly, M. C. (2001). Shopping online for freedom, control and fun. California Management Review, 43(2), 34-55

Wu, J. N. 2014. Impacts of service vendors' characteristics and consumers' disposition to trust on mobile commerce trust intention. Comm. Res. 5:94-101. (In Chinese.).

Xu, C. 2016. The Impact of Trust Tendency, Social Identity Information and Expectation on Strangers' Trust. Yunnan Normal University, Kunming, China. (In Chinese.)

Yang, B., \& Lester, D. (2004) Attitudes toward buying online. Cyber Psychology \& Behavior, 7,(1), 85-91.Yang, B., Lester, D., \& James, S. (2007). Attitudes toward buying online as predictors of shopping online for British and American respondents. Cyber Psychology and Behavior, 10(2), 198-203.

Zhai, X. and T. Xue. 2014. Social Trust: Theories and their Practices. Renmin University of China, Beijing.

Zhang, H. and Y. W. Jiang. 2016. Empirical analysis on the influencing factors of consumer online shopping behavior decision-making based on revised TAM model. J. Comm. Econ. 14:36-38. (In Chinese.) 